\title{
Leaching of Metals from Hydrometallurgical Residue by Sulfuric Acid
}

\author{
EL Bar D* and Barket D \\ Chemical Industry Department, University of Biskra, Algeria \\ *Corresponding author: Elbar D, Laboratory of Chemical Molecular, University of Biskra 07000, Algeria

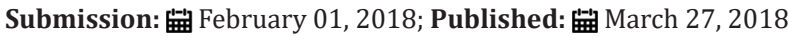

\begin{abstract}
A direct leaching on the hydrometallurgical residue with sulfuric acid was developed in this work. The influence of leaching temperature, the leaching time, the particle size and the sulfuric acid concentration was examined. Results of leaching studies that the recovery extraction of $\mathrm{Zn}$, Fe and $\mathrm{Cu}$ for hydrometallurgical residue increases with increasing acid concentration and temperature; while it decreases with particle size.

The optimum conditions for the extraction $\mathrm{Zn}$, Fe and $\mathrm{Cu}$ are: leaching temperature $85^{\circ} \mathrm{C}$; sulfuric acid concentration 2 mol.L-1; the smaller particle size $63 \mu \mathrm{m}$ and the solid-to-liquid ratio 1:10. After $2 \mathrm{~h}$ of leaching treatment at these optimum conditions, over $80 \%$ of metals are extracted from the residues.

The shrinking core model for the diffusion was established to control the mechanism with surface chemical reaction as the rate controlling step for the dissolution process.
\end{abstract}

Keyword: Hydrometallurgical residue; Leaching; Sulfuric acid; Dissolution kinetics

\section{Introduction}

The hydrometallurgical processes are regarded as more eco-friendly for treating materials having a low zinc content. Zinc is primarily produced from sphalerite ores; however, some zinc is produced from oxide-carbonate ores and different secondary resources such as zinc ash, zinc dross, leach residues, etc. Pyrometallurgical and hydrometallurgical routes or their combination can be employed for treating secondary materials [1].

Zinc, the $25^{\text {th }}$ most abundant element, is widely distributed in nature, making up between $0.0005 \%$ and $0.02 \%$ of the Earth's crust [2]. The estimated world production of zinc is 7.1 million metric tons. Zinc is an important metal required for many applications from metal products to chemical, paint, and agriculture industries. It is mainly recovered from sphalerite $(\mathrm{ZnS})$, which is commonly associated to other sulphide minerals, such as chalcopyrite $\left(\mathrm{CuFeS}_{2}\right)$, galena (PbS), Pyrite (FeS2) [3-7].

Generally speaking, hydrometallurgical processes without pretreatment are more advantageous and less harmful than pyrometallurgical processes from an economic and environmental point of view, especially for complex ores [8]. Zinc exists in the earth crust predominantly as sphalerite is most important ores occurring in Algeria (chaabet -el-Hamra, Setif). Conventional zinc concentrates typically contain 5-10\% of iron, the iron commonly associated with zinc concentrate can be present as either a replacement for zinc in sphalerite or marmatite or as separate minerals, such as pyrite [9-11].
The objectives of this work are to develop a hydrometallurgical process for recovering $\mathrm{Zn}, \mathrm{Fe}$ and $\mathrm{Cu}$ from hydrometallurgical residue of Chaabet El Hamra in acidic solution are reported and discussed.

\section{Experimental}

\section{Hydrometallurgical residue characterization}

Table 1: Chemical composition of hydrometallurgical residue (mass fraction, \%).

\begin{tabular}{|c|c|c|c|c|}
\hline \multirow{2}{*}{ Elements } & $\mathrm{Zn}$ & $\mathrm{S}$ & $\mathrm{Fe}$ & $\mathrm{Cu}$ \\
\cline { 2 - 5 } & 41.61 & 39.38 & 13.71 & 0.14 \\
\hline
\end{tabular}

Table 2: Mineralogical composition of head sample (mass fraction, \%).

\begin{tabular}{|c|c|c|c|c|c|}
\hline Sphalerite & Quartz & Galena & Pyrite & Chaclopyrite & $\begin{array}{c}\text { Copper } \\
\text { sulfide }\end{array}$ \\
\hline 50.06 & 14.3 & 20.08 & 13.11 & 0.12 & 2.33 \\
\hline
\end{tabular}

The hydrometallurgical residue was collected from zinc obtained from chaabet -el-Hamra, Setif of Algeria. Tables 1\&2 show the chemical compositions of the feed and the mineralogical analysis results of bulk concentrate, respectively. The major minerals present in the concentrate were sphalerite $(\mathrm{ZnS})$, marmatite ( $\mathrm{ZnFeS}$ ), quartz (SiO2), and other minerals including $\mathrm{Pb}$ (Tables 1\&2).

Figure1 shows the XRD pattern of the zinc sulfide concentrate and Figure 2 shows the Optical micrograph for hydrometallurgical residue (Figure 1\&2). 


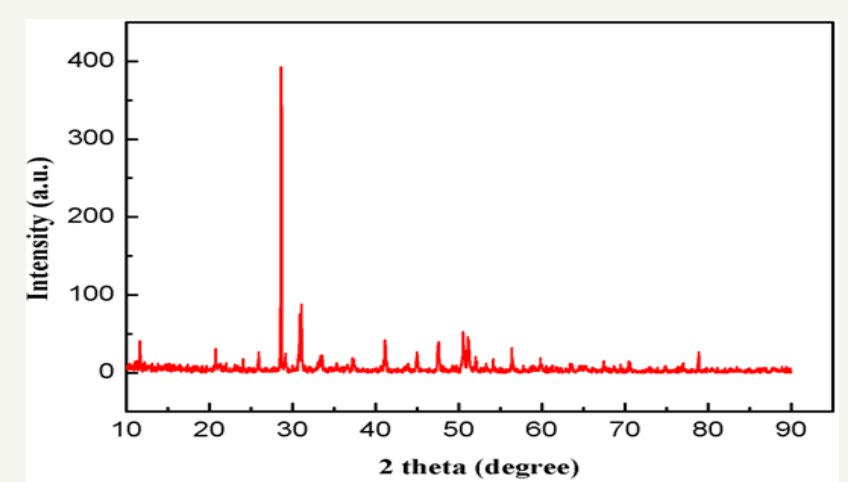

Figure 1: XRD pattern for hydrometallurgical residue.

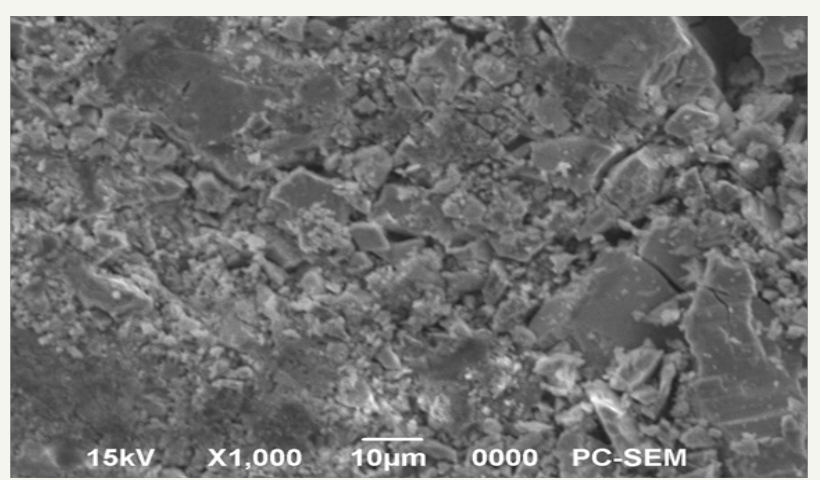

Figure 2: Optical micrograph of hydrometallurgical residue (X1000).

\section{Leaching procedure}

Table 3: Experimental parameters and their levels for leaching.

\begin{tabular}{|c|c|c|c|c|}
\hline Parameter & $\mathbf{1}$ & $\mathbf{2}$ & $\mathbf{3}$ & $\mathbf{4}$ \\
\hline $\mathrm{C}\left(\mathrm{H}_{2} \mathrm{SO}_{4}\right) /($ mol.L- $)$ & 0.25 & 0.5 & 1 & 2 \\
\hline Temperature $\left({ }^{\circ} \mathrm{C}\right)$ & 25 & 45 & 65 & 85 \\
\hline Particle size $(\mu \mathrm{m})$ & 63 & 125 & 160 & 200 \\
\hline
\end{tabular}

All the chemicals used were of analytical grade. The leaching experiments were carried out in flask fitted with a reflux condenser and a mechanical stirrer. The flask was placed on a thermostatically controlled heating mantle [12-14]. The solution temperature was controlled to specific values with continuously monitored by a thermometer. Samples of clay weighing $10 \mathrm{gm}$ were taken in $100 \mathrm{ml}$ of leaching solution. The order of levels was randomly chosen as the order of experiments to avoid any bias (Table 3). Possible interactions between variables were not considered significantly and were therefore not covered in the matrix, which focused on the main effects of the three independent parameters. Finally, the validity of this assumption was checked using the confirmation experiment with triplicate measures at optimum conditions [15] (Table 3).

The optimum concentrations of the acids were determined by leaching in $(0.25,0.5,1$ and 2 (mol.L-1)) sulfuric acid solutions. The subsequent leaching was performed in the optimized acid concentrations at temperatures of $\left(25,45,65\right.$ and $\left.85^{\circ} \mathrm{C}\right)$ for $(0.5$, $1,1.5$ and 2 hour) at each temperature. A variable speed stirrer operated at a speed of 100rpm was maintained during in all leaching experiments at $1 \mathrm{MPa}$. At the end of leaching for a specific period of time at a specific temperature of leaching solution was taken out of the round bottom flask by a pipette. The collected sample of leach liquor was cooled, filtered and used for the concentrate of $\mathrm{Zn}, \mathrm{Fe}$ and $\mathrm{Cu}$ metals estimation with an atomic absorption spectrometer.

\section{Results and Discussion}

\section{Leaching mechanism}

In this leaching system, $\mathrm{ZnS}$ and sulfate inter-reacted and generated $\mathrm{S}, \mathrm{ZnSO}_{4}, \mathrm{FeSO}_{4}, \mathrm{CuSO}_{4}, \mathrm{H}_{2} \mathrm{O}$, etc $[4,10]$. The dissolution reaction proceeds according to the following chemical equilibrium:

$$
\begin{aligned}
& \mathrm{ZnS}(\mathrm{s})+\mathrm{H}_{2} \mathrm{SO}_{4}====\mathrm{ZnSO}_{4}+\mathrm{H}_{2} \mathrm{~S}(\mathrm{aq}) \\
& 2 \mathrm{ZnFeS}+2 \mathrm{H}_{2} \mathrm{SO}_{4}====2 \mathrm{FeSO}_{4}+2 \mathrm{ZnSO}_{4}+2 \mathrm{H}_{2} \mathrm{~S} \\
& 2 \mathrm{FeSO}_{4}+\mathrm{H}_{2} \mathrm{SO}_{4}====\mathrm{Fe}_{2}\left(\mathrm{SO}_{4}\right)_{3}+\mathrm{H}_{2} \mathrm{O} \\
& \mathrm{H}_{2} \mathrm{~S}+\mathrm{Fe}_{2}\left(\mathrm{SO}_{4}\right)_{3}====2 \mathrm{FeSO}_{4}+\mathrm{H}_{2} \mathrm{SO}_{4}+\mathrm{SO} \\
& \mathrm{CuS}(\mathrm{s})+\mathrm{H}_{2} \mathrm{SO}_{4}====\mathrm{CuSO}_{4}+\mathrm{H}_{2} \mathrm{~S}(\mathrm{aq})
\end{aligned}
$$

Hydrogen sulfide is distributed between aqueous and gas phases according to:

$$
\mathrm{H}_{2} \mathrm{~S}(\mathrm{aq})====\mathrm{H}_{2} \mathrm{~S}(\mathrm{~g})
$$

The leaching efficiencies of $\mathrm{Zn}, \mathrm{Fe}$ and $\mathrm{Cu}$ metals were calculated according to the following equation:

Metals extraction $=\left[\left(\mathrm{C}_{1} \times \mathrm{V}_{1}\right) /\left(\mathrm{W}_{1} \times \mathrm{C}_{2}\right)\right] \times 100 \%$

Where

$\mathrm{W}_{1}$ (g): the mass of $\mathrm{Zn}, \mathrm{Fe}$ and $\mathrm{Cu}$ metals content in the hydrometallurgical residue,

$\mathrm{V}_{1}(\mathrm{~L})$ : the volume of leaching solution,

$\mathrm{C}_{1}(\mathrm{~g} / \mathrm{L})$ : the metals concentrations in the leaching solution,

$\mathrm{C}_{2}(\%)$ : the percent of metals $\mathrm{Zn}, \mathrm{Fe}$ and $\mathrm{Cu}$ metals content in the hydrometallurgical residue.

\section{Effect of leaching temperature}

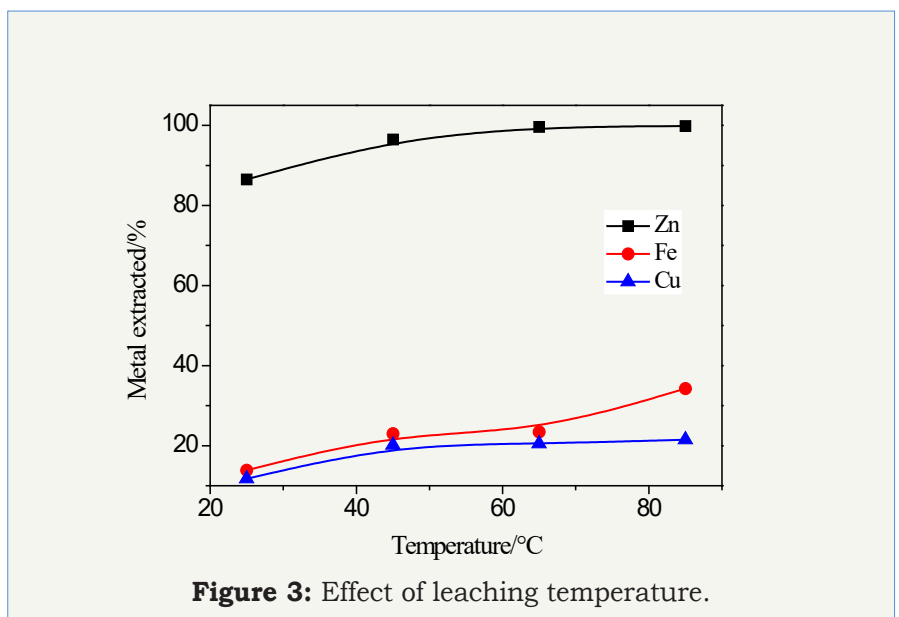

The leaching temperature is an important thermodynamic parameter. The effect of temperature on the recovery of metals 
$\mathrm{Zn}, \mathrm{Fe}$ and $\mathrm{Cu}$ was studied at constant sulfuric acid concentration (2mol.L-1), particle size $(63 \mu \mathrm{m})$, and leaching time ( $2 \mathrm{~h})$.

Figure 3 shows that the solubility of $\mathrm{ZnS}, \mathrm{FeS}$ and $\mathrm{CuS}$ in acidic solution is enhanced with increasing temperature; at $25{ }^{\circ} \mathrm{C}$ about 86.49\% $\mathrm{Zn}, 13.87 \% \mathrm{Fe}$ and $11.74 \% \mathrm{Cu}$ were extracted; while the maximum extraction of this metals $\mathrm{Zn}, \mathrm{Fe}$ and $\mathrm{Cu}$ from the residue occurred with contribution rates of $99.82 \%, 30.76 \%$, and $20.26 \%$ respectively at temperature of leaching solution $85^{\circ} \mathrm{C}$ (Figure 3 ).

\section{Effect of leaching time}

The effect of leaching time on the recovery of metals Zn, Fe and $\mathrm{Cu}$ were studied at constant sulfuric acid concentration $\left(2 \mathrm{~mol} . \mathrm{L}^{-1}\right)$, particle size $(63 \mu \mathrm{m})$ for solid-to-liquid ratio (1:10) and at a temperature of leaching solution of $85^{\circ} \mathrm{C}$.

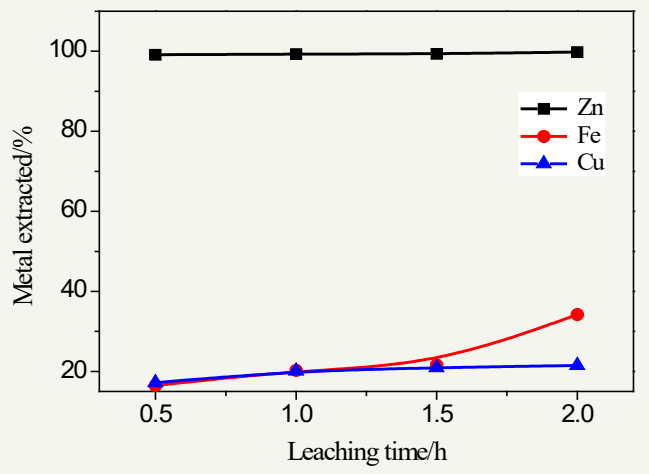

Figure 4: Effect of leaching time on leaching.

Figure 4 shows that with increasing time the solubility of $\mathrm{ZnS}$, $\mathrm{FeS}$ and $\mathrm{CuS}$ in acidic solution is enhanced with increasing time; when the leaching time was over $1 \mathrm{~h}$, the curve of leaching rate was changed to be steady; the suitable leaching time is $2 \mathrm{~h} \mathrm{Xu}$ et al. [11] they seen that the rate of iron and silica dissolution decreases greatly with an increase in leaching time. Thus, leaching time for higher productivity was standardized to $120 \mathrm{~min}$ on the basis of leaching selectivity of zinc (Figure 4).

\section{Effect of particle sizes}

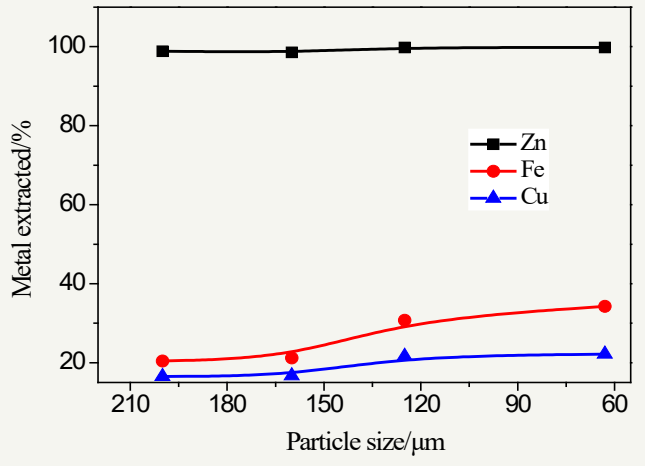

Figure 5: Effect of leaching time on leaching.
The effect of particle size had a significant effect on the leaching of the recovery of metals $\mathrm{Zn}, \mathrm{Fe}$ and $\mathrm{Cu}$ was studied at constant sulfuric acid concentration of $2 \mathrm{mol.l}^{-1}$, leaching time of $2 \mathrm{~h}$ and solid-to-liquid ratio (1:10) at leaching temperatures(85 ${ }^{\circ} \mathrm{C}$ ). Measurement of the reaction rates on the influence of particle sizes on the recovery of metals $\mathrm{Zn}, \mathrm{Fe}$ and $\mathrm{Cu}$ dissolution in $\mathrm{H}_{2} \mathrm{SO}_{4}$ was investigated for four different sized fractions; the results are summarized in Figure 5. The maximum extraction rate of $\mathrm{Zn}, \mathrm{Fe}$ and $\mathrm{Cu}$, from the residue used in this study obtained at the smaller particle size of $63 \mu \mathrm{m}$ (Figure 5).

\section{Effect of acid Concentration}

The effect of sulfuric acid on the leaching of the recovery of metals $\mathrm{Zn}, \mathrm{Fe}$ and $\mathrm{Cu}$ was studied at constant temperature (85 $\left.{ }^{\circ} \mathrm{C}\right)$,particle size $(63 \mu \mathrm{m})$; leaching time of $2 \mathrm{~h}$ and solid-to-liquid ratio (1:10). The results of the effect of $\mathrm{H}_{2} \mathrm{SO}_{4}$ concentration on of the recovery of metals are illustrated in Figure 6. It is apparent from figure 4 that the recovery of $\mathrm{Zn}, \mathrm{Fe}$ and $\mathrm{Cu}$ increases with increasing acid concentration. It appears that the effect was very mild when the acid concentration was increased from 1-2M. For efficient recovery of $\mathrm{Zn}, \mathrm{Fe}$ and $\mathrm{Cu}(99.82 \%, 30.76 \%$ and $20.26 \%$, respectively); $2.00 \mathrm{~mol} / \mathrm{L} \mathrm{H}_{2} \mathrm{SO}_{4}$ in the leaching solution was the best (Figure 6).

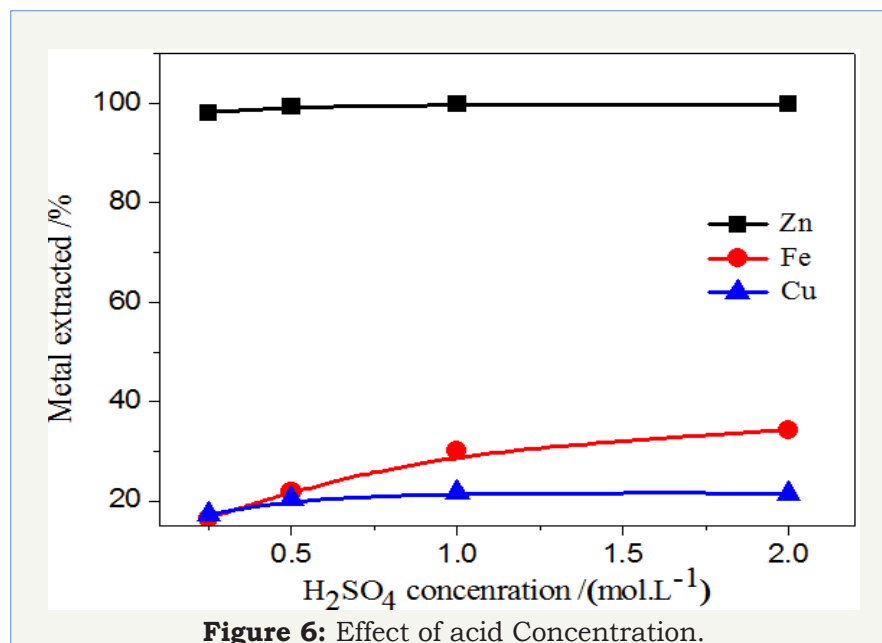

\section{Dissolution kinetic models}

The kinetic of shrinking core model (shrinking core) was used by Hackl et al. [16], explains the kinetics of chemical oxidative leach chalcopyrite. In bioleaching, it has been exploited for the dissolution of complex sulphide Gomez et al. [17], for the dissolution of sphalerite Lizama [18].

If we consider $\mathrm{X}$ as the fraction leached at time $\mathrm{t}$, the fraction not dissolved is given by:

$$
\begin{aligned}
& 1-X=\left(1-k t / r_{i}\right)^{3} \\
& 1-(1-X)^{3 / 2}=\left(k / r_{i}\right) t
\end{aligned}
$$

ri: the particule radius and $\mathrm{k}$ : constant linear velocity.

It can be applied to the results of our experimental trials. The assumptions underlying this model correspond to the part of the 
curve after the leaching of oxide (after 20 minutes) where the particle is leached surrounded by a layer of insoluble products of the reaction and before the termination of the reaction. The

Table4: The values of term kinetic models proposed for leaching solution at different temperatures for smaller particle size (63 $\mu$ m) by $2 \mathrm{M} \mathrm{H}_{2} \mathrm{SO}_{4}$.

\begin{tabular}{|c|c|c|c|c|c|c|}
\hline \multirow{2}{*}{ Temperature $\left({ }^{\mathbf{0}} \mathbf{C}\right)$} & \multicolumn{2}{|c|}{ Zinc } & \multicolumn{2}{c|}{ Copper } \\
\cline { 2 - 7 } & Fraction Leached & $\mathbf{1 - ( 1 - X ) ) ^ { 3 / 2 }}$ & Fraction Leached & 1-(1-X) $)^{3 / 2}$ & Fraction Leached & 1-(1-X) $)^{3 / 2}$ \\
\hline 25 & 0.83466 & 0.541 & 0.11645 & 0.04043 & 0.00255 & $9.00 \mathrm{E}-04$ \\
\hline 25 & 0.83606 & 0.4527 & 0.11714 & 0.04068 & 0.0226 & 0.0076 \\
\hline 25 & 0.86138 & 0.4825 & 0.11744 & 0.04079 & 0.03281 & 0.01106 \\
\hline 25 & 0.86492 & 0.487 & 0.11749 & 0.04081 & 0.03864 & 0.01305 \\
\hline 45 & 0.95665 & 0.6488 & 0.06342 & 0.0217 & 0.18967 & 0.06771 \\
\hline 45 & 0.95754 & 0.6512 & 0.07363 & 0.0252 & 0.19208 & 0.06863 \\
\hline 45 & 0.96474 & 0.6721 & 0.10425 & 0.0361 & 0.19716 & 0.07059 \\
\hline 45 & 0.96494 & 0.6728 & 0.23036 & 0.0836 & 0.20144 & 0.07224 \\
\hline 65 & 0.9912 & 0.7936 & 0.06415 & 0.02186 & 0.20139 & 0.07223 \\
\hline 65 & 0.99317 & 0.8103 & 0.16038 & 0.05661 & 0.20472 & 0.07352 \\
\hline 65 & 0.99325 & 0.81102 & 0.22818 & 0.08272 & 0.20406 & 0.07326 \\
\hline 65 & 0.99642 & 0.8471 & 0.23445 & 0.08521 & 0.20488 & 0.07358 \\
\hline 85 & 0.99172 & 0.7977 & 0.16475 & 0.05825 & 0.17166 & 0.06085 \\
\hline 85 & 0.99342 & 0.8127 & 0.2187 & 0.079 & 0.2026 & 0.07269 \\
\hline 85 & 0.99821 & 0.8786 & 0.30035 & 0.1124 & 0.21604 & 0.07793 \\
\hline 85 & 0.99821 & 0.8786 & 0.34263 & 0.1305 & 0.21495 & 0.07751 \\
\hline
\end{tabular}

To apply this kinetic model, we calculated based on the time the term $1-(\mathrm{X}-1)^{3 / 2}($ Table 4$)$. assumptions therefore correspond to the time interval between 30 and 120 minutes of leaching.
The modeling equations and kinetic constants found are listed in Table 5 \& 6.

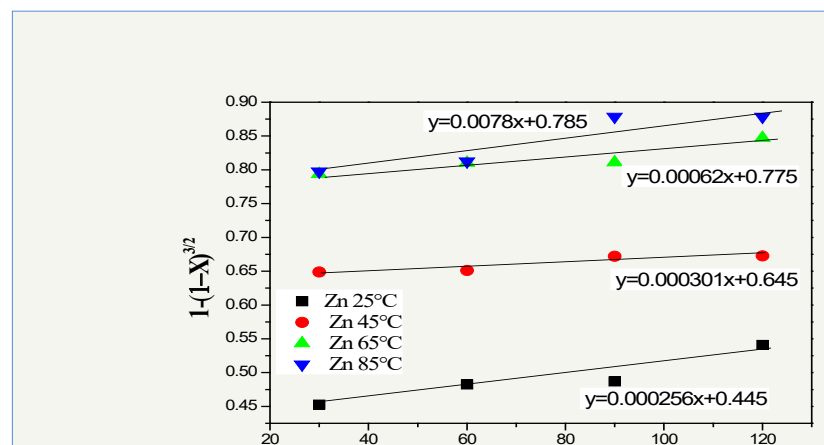

(a) Time of leaching /(min)

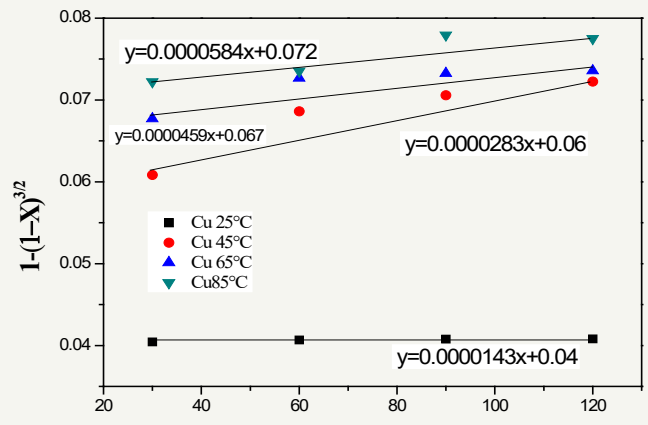

(c) Time of leaching /(min)

Figure 7: Plot of $\left[1-(\mathrm{X}-1)^{3 / 2}\right]$ as a function of leaching time (a) $\mathrm{Zn}$, (b) Fe and (c) for Cu. 
Table 5: The modeling equations for leaching dissolution at different temperatures.

\begin{tabular}{|c|c|c|c|}
\hline \multirow{2}{*}{ Temperature $\left({ }^{\circ} \mathbf{C}\right)$} & Zn & Fe & Cu \\
\cline { 2 - 4 } & Modeling Equations & Modeling Equations & Modeling Equations \\
\hline 25 & $\mathrm{y}=0.000256 \mathrm{x}+0.445$ & $\mathrm{y}=0.000101 \mathrm{x}+0.0008$ & $\mathrm{y}=0.0000143 \mathrm{x}+0.04$ \\
\hline 45 & $\mathrm{y}=0.000301 \mathrm{x}+0.645$ & $\mathrm{y}=0.000197 \mathrm{x}+0.02$ & $\mathrm{y}=0.0000283 \mathrm{x}+0.06$ \\
\hline 65 & $\mathrm{y}=0.00062 \mathrm{x}+0.775$ & $\mathrm{y}=0.000501 \mathrm{x}+0.025$ & $\mathrm{y}=0.0000459 \mathrm{x}+0.067$ \\
\hline 85 & $\mathrm{y}=0.000785 \mathrm{x}+0.785$ & $\mathrm{y}=0.00067 \mathrm{x}+0.05$ & $\mathrm{y}=0.0000584 \mathrm{x}+0.072$ \\
\hline
\end{tabular}

Table 6: The values of rate constants and their correlation coefficients for leaching dissolution at different temperatures.

\begin{tabular}{|c|c|c|c|c|c|c|}
\hline \multirow[b]{2}{*}{ Temperature $\left({ }^{\circ} \mathrm{C}\right)$} & \multicolumn{2}{|c|}{ Zn } & \multicolumn{2}{|c|}{$\mathbf{F e}$} & \multicolumn{2}{|c|}{$\mathrm{Cu}$} \\
\hline & $\begin{array}{l}\text { Kinetic Constants } \\
\mathbf{k}^{\prime}=\mathrm{k} / \mathrm{ri}\left(\mathbf{m i n}^{-1}\right)\end{array}$ & $\begin{array}{c}\text { Correlation } \\
\text { Coefficient } \mathbf{R}^{2}\end{array}$ & $\begin{array}{c}\text { Kinetic Constants } \\
\mathbf{k}^{\prime}=k / \mathrm{ri}\left(\mathbf{m i n}^{-1}\right)\end{array}$ & $\begin{array}{c}\text { Correlation } \\
\text { Coefficient } \mathbf{R}^{2}\end{array}$ & $\begin{array}{c}\text { Kinetic Constants } \\
\mathbf{k}^{\prime}=\mathrm{k} / \mathrm{ri}\left(\mathbf{m i n}^{-1}\right)\end{array}$ & $\begin{array}{c}\text { Correlation } \\
\text { Coefficient } \mathbf{R}^{2}\end{array}$ \\
\hline 25 & 0.000256 & 0.7586 & 0.000101 & 0.9045 & 0.0000143 & 0.9823 \\
\hline 45 & 0.000301 & 0.9586 & 0.000197 & 0.8242 & 0.0000283 & 0.6591 \\
\hline 65 & 0.00062 & 0.8573 & 0.000501 & 0.6127 & 0.0000459 & 0.6127 \\
\hline 85 & 0.000785 & 0.7091 & 0.00067 & 0.8505 & 0.0000584 & 0.7036 \\
\hline
\end{tabular}

Figure 7 shows that in the time interval considered leaching (30 to 120 minutes), there is a linearity between the term $\left[1-(1-\mathrm{X})^{3 / 2}\right]$ and the leaching time, we can therefore assume that the reweaving core model is consistent with the dissolution of zinc, iron and copper concentrate processed. Well understood the modeling equations are not of the type $y=a x$ that would leave axis origin but shows the relationship of the type $y=a x+b$ where $b$ is the rapid dissolution of the oxides in the first 20minutes (Figure 7).

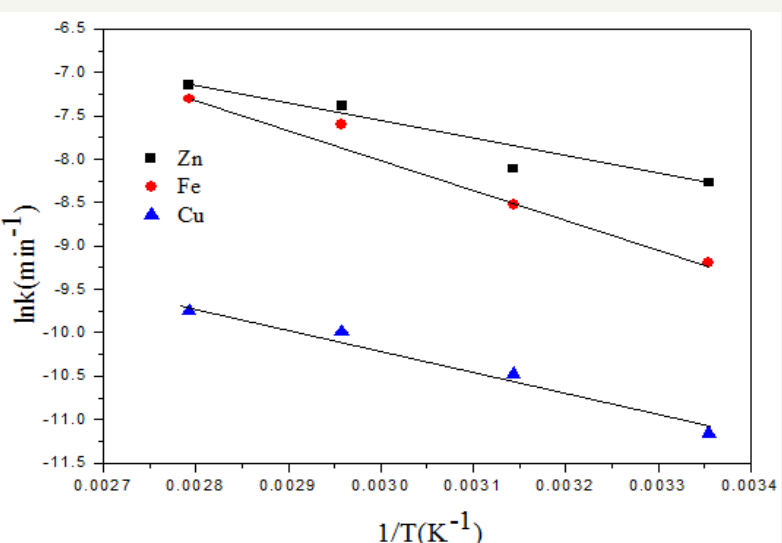

Figure 8: Arrhenius plot for determining activation energy Ea.

The slopes of the lines in Figure 7 is equal to $\mathrm{k} / \mathrm{r}_{\mathrm{i}}$ which follow the Arrhenius law $\mathrm{k}=\mathrm{A} \mathrm{e}^{\mathrm{Ea} / \mathrm{RT}}$ with $\mathrm{A}$ is the Arrhenius constant, $\mathrm{Ea}$ is the activation energy , $\mathrm{T}$ the absolute temperature and $\mathrm{R}$ is the Boltzmann constant. This law allows us to calculate the activation energy $\mathrm{Ea}$ is the minimum that the reactants must acquire to be able to react and turn into a product of leaching reaction energy. This energy is equal to the value of the slope $\ln \mathrm{k}$ Arrhenius graph of the inverse function of the temperature in Figure 8. Figure 8 show that the dissolution of zinc gives a small linear dependence between the logarithm of the rate constant and 1/T. As for iron and copper against, there is a great dependency. The value of the activation energy is calculated by multiplying the slope of the Arrhenius curve by the value of the Boltzmann constant $(8.314 \mathrm{~J} / \mathrm{mol} . \mathrm{K})$.
The calculated value for zinc Ea is $46.63 \mathrm{~kJ} / \mathrm{mol}$, for iron Ea is $28.09 \mathrm{~kJ} / \mathrm{mol}$ and for copper Ea is $20.91 \mathrm{~kJ} / \mathrm{mol}$. When the value of the activation energy is between 4.2 and $12.6 \mathrm{~kJ} / \mathrm{mol}$, the reaction rate is controlled purely by the diffusion and when this value is greater than $46 \mathrm{~kJ} / \mathrm{mol}$, the control is purely chemical kinetics (Figure 8).

\section{Conclusion}

This systematic study showed that four parameters, including temperature, $\mathrm{H}_{2} \mathrm{SO}_{4}$ concentration, particle size, time of leaching, all had significant effects on the recovery of metals from a hydrometallurgical residue.

On the basis of the results of the characterization and dissolution studies undertaken, the following conclusions can be drawn:

i. The recovery of $\mathrm{Zn}, \mathrm{Fe}$ and $\mathrm{Cu}$ from a hydrometallurgical residue leaching was studied. It is found that temperature is an important parameter for Zinc, Iron and Copper extraction.

ii. The results of leaching investigations showed that the particle size and sulfuric acid concentration also have significant effects on the recovery of Zinc, Iron and Copper.

iii. The optimum leaching conditions to the maximum extraction of $\mathrm{Zn}, \mathrm{Fe}$ and $\mathrm{Cu}$ from the residue occur at temperature leaching $85{ }^{\circ} \mathrm{C}, \mathrm{H}_{2} \mathrm{SO}_{4}$ concentration $2 \mathrm{~mol} / \mathrm{L}$, particle size $63 \mu \mathrm{m}$; after $2 \mathrm{~h}$ of treatment at the optimum conditions, the extraction rates from the residue are $99.82 \% \mathrm{Zn}, 30.76 \% \mathrm{Fe}$ and $20.26 \% \mathrm{Cu}$ is suitable for the recovery of $\mathrm{Zn}, \mathrm{Fe}$ and $\mathrm{Cu}$ from the hydrometallurgical residues.

iv. The overall results of the dissolution studies indicated that the data fitted the shrinking core model for the diffusion controlled mechanism, with surface chemical reaction as the rate controlling step.

This is consistent with the following relation:

$\left[1-(1-\mathrm{X})^{3 / 2}\right]=\mathrm{A} \exp ^{(\mathrm{Ea} / \mathrm{RT})} \mathrm{t}$. The activation energy, Ea for zinc is $46.63 \mathrm{~kJ} / \mathrm{mol}$, that for iron is $28.09 \mathrm{~kJ} / \mathrm{mol}$ and for copper is $20.91 \mathrm{~kJ} /$ 
mol. Finally, the leaching by sulfuric acid give the best dissolution of zinc, iron and copper from the hydrometallurgical residue of chaabet -el-Hamra, Setif of Algeria.

\section{References}

1. Deniz Turan M, Soner Altundogan H, Fikret Tqmen (2004) Recovery of zinc and lead from zinc plant residue. Hydrometallurgy 75(1-4): 169176.

2. Çopur M, Ozmetin C, Ozmetin E, Kocakerim MM (2004) Optimization study of the leaching of roasted zinc sulphide concentrate with sulphuric acid solutions. Chemical Engineering and Processing 43(8): 1007-1014.

3. Gu Y, Zhang TA, Liu Y, Mu WZ, Zhang WG, et al. (2010) Pressure acid leaching of zinc sulfide concentrate. Trans. Nonferrous Met Soc China 20(1): s136-s140.

4. Rușen A, Sunkar AS, Topkaya YA (2008) Zinc and lead extraction from Çinkur leach residues by using hydrometallurgical method. Hydrometallurgy 93 (1-2): 45-50.

5. Olubambi PA, Borode JO, Ndlovu S (2006) Sulphuric acid leaching of zinc and copper from Nigerian Complex Sulphide Ore in the presence of hydrogen peroxide. The Journal of The Southern African Institute of Mining and Metallurgy 106 (2006): 765-770.

6. Santos SMC, Ismael MRC, Correia MJN, Reis MTA, Deep A, et al. (2007) Hydrometallurgical treatment of a zinc concentrate by atmospheric direct leach process. Proceedings of European Congress of Chemical Engineering (ECCE-6) Copenhagen 16-20.

7. Xu H, Wei C, Li C, Fan G, Deng Z, et al. (2012) Leaching of a complex sulfidic, silicate-containing zinc ore in sulfuric acid solution under oxygen pressure. Separation and Purification Technology 85: 206-212.

8. Abramov AA, Avdohin VM (1997) Oxidation of sulfide minerals in benefication process. Gordon and Breach Science Publishers, The Netherlands, p. 321

9. Moradi S, Monhemius AJ (2011) Mixed sulphide-oxide lead and zinc ores: Problems and solutions. Minerals Engineering 24 (10): 1062-1076.

10. Xu H, Wei C, Li C, Fan G, Deng Z, et al. (2010) Sulfuric acid leaching of zinc silicate ore under pressure. Hydrometallurgy 105(1-2): 186-190.

11. Li C, Wei C, Xu HS, Li M, Li X, et al. (2010) Oxidative pressure leaching of sphalerite concentrate with high indium and iron content in sulfuric acid medium. Hydrometallurgy 102(1-4): 91-94.

12. KL Bhat, KA Natarajan (1987) Transactions of the Indian Institute of Metals 40: 361-371.

13. JO Claassen, EHO Meyer, JRennie, RF Sandenbergh (2002) Iron precipitation from zinc-rich solutions: defining the Zincor Process. Hydrometalllurgy 67(1-3): 87-108.

14. Elgersma F, Kamst GF, Witkamp GJ, van Rosmalen GM (1992) Acidic dissolution of zinc ferrite. Hydrometallurgy 29(1-3): 173-192.

15. Safarzadeh MS, Moradkhani D, Ilkhchi MO, Golshan NH (2008) Determination of the optimum conditions for the leaching of $\mathrm{Cd}$ $\mathrm{Ni}$ residues from electrolytic zinc plant using statistical design of experiments. Separation and Purification Technology 58(3): 367-376.

16. Hackl RP, Dreisinger D, Peter E, King JA (1995) Passivation of chalcopyrite during oxidative leaching in sulfate media. Hydrometallurgy 39(1-3): $25-48$

17. Gómez C, Limpo JL, De Luis A, Blàzquez ML, Gonzalez F, et al. (1997) Hydrometallurgy of bulk concentrates of Spanish complex sulphides: chemical and bacterial leaching. Canadian Metallurgical Quarterly 36(1): $15-23$.

18. Lizama HM, Fairweather MJ, Dai Z, Allegretto TD (2003) How does bioleaching start? Hydrometallurgy 69(1-3): 109-116.

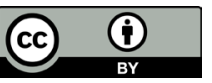

Creative Commons Attribution 4.0 International License

For possible submissions Click Here

\section{Submit Article}

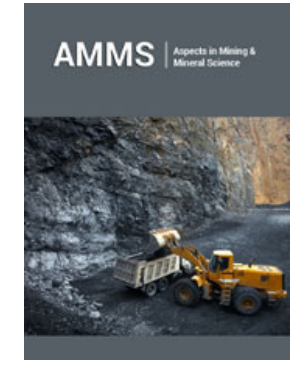

Aspects in Mining \& Mineral Science

\section{Benefits of Publishing with us}

- High-level peer review and editorial services

- Freely accessible online immediately upon publication

- Authors retain the copyright to their work

- Licensing it under a Creative Commons license

- Visibility through different online platforms 